8: To $450 \mathrm{mg}$ ( $1.22 \mathrm{mmol}$ ) of compound 7 was added $2 \mathrm{~mL}$ pyridine. The mixture was stirred at room temperature and then $549 \mathrm{mg}(2 \mathrm{mmol})$ of tert-butyldiphenylsilyl chloride was added by syringe. The mixture was stirred at room temperature for $1 \mathrm{~h}$. After addition of ethyl acetate $(15 \mathrm{~mL})$ the mixture was washed with $\mathrm{H}_{2} \mathrm{O}, 1 \mathrm{v}$ $\mathrm{HCl}$, and saturated aqueous $\mathrm{NaHCO}_{3}$, and then dried over $\mathrm{Na}_{2} \mathrm{SO}_{4}$. The organic solvent was removed under vacuum. The residue was purified by silica gel column chromatography (ethyl acetate, hexane $=1,10$ to $1 / 5$ ) to furnish $683 \mathrm{mg}$ of 8 in $92 \%$ yield: $[\alpha]_{1}^{2.3}=-54.8(c=0.61, \mathrm{MeOH}): R_{\mathrm{f}}=0.63$ (ethyl acetate thexane $=12$ ) ${ }^{1} \mathrm{H} \mathrm{NMR}\left(500 \mathrm{MHz}, \mathrm{CDCl}_{3}\right): \delta=0.96(2.9 \mathrm{H}) .1 .25(\mathrm{~s} .3 \mathrm{H}), 1.29(\mathrm{~s}, 3 \mathrm{H}) .3 .09$ (ddd $1 \mathrm{H}, J=10.10,10 \mathrm{~Hz}), 3.29(\mathrm{~m}, 3 \mathrm{H}), 3.59(\mathrm{~m}, 1 \mathrm{H}), 3.80(\mathrm{dd}, 1 \mathrm{H}, J=10.10 \mathrm{H} L)$ $4.19(\mathrm{dd}, 1 \mathrm{H}, J=2.0 .4 .5 \mathrm{~Hz}) .4 .48(\mathrm{dd}, 1 \mathrm{H} . J=2.0 .20 \mathrm{~Hz}) .4 .95(\mathrm{~s} .1 \mathrm{H}) .7 .38 \mathrm{~mm}$ $20 \mathrm{H}):{ }^{13} \mathrm{C}$ NMR $\left(125 \mathrm{MHz}, \mathrm{CDCl}_{3}\right): \delta=22.3,25.7,26.0,26.8,61.7 .62 .9 .65 .6$ 71.4.74.0.77.5. 79.0, 98.8, 127.1. 127.3. 127.6, 128.1. 128.2. 128.3. 128.6. 129.5 129.6. 135.3, 135.5. 143.3, 143.4; HRMS for $\mathrm{C}_{38} \mathrm{H}_{45} \mathrm{O}_{4} \mathrm{NSiCs}\left[M+\mathrm{Cs}^{+}\right]$: calcd 740.2172 , found 740.2168

9: To a solution of periodinane [7] ( $548 \mathrm{mg}, 0.9 \mathrm{mmol})$ in $10 \mathrm{~mL} \mathrm{CH} \mathrm{Cl}_{2}$ was added $548 \mathrm{mg}$ of $8 \mathrm{in} 2 \mathrm{~mL} \mathrm{CH}_{2} \mathrm{Cl}_{2}$. The mixture was stirred at room temperature for $3.5 \mathrm{~h}$ $2 \mathrm{~mL}$ of $1 \mathrm{~N} \mathrm{NaOH}$ was added, and the mixture was stirred for additional $10 \mathrm{~min}$ The organic layer was then washed with $1 \times \mathrm{NaOH}$ and dried over $\mathrm{MgSO}_{4}$, and the solvent was removed under vacuum to give $438 \mathrm{mg}$ of 9 in $80 \%$ yield: $[x]_{15}^{3}=-19.0$ $(c=1.05 . \mathrm{MeOH}): R_{\mathrm{f}}=0.41$ (ethyl acetate hexane $\left.=144\right) .{ }^{1} \mathrm{HNMR}(500 \mathrm{MHz}$ $\left.\mathrm{CDC} \mathrm{l}_{3}\right): \delta=1.06(\mathrm{~s}, 9 \mathrm{H}), 1.33(\mathrm{~s} .6 \mathrm{H}), 3.39-3.46(\mathrm{~m}, 1 \mathrm{H}), 3.48(\mathrm{dd}, 1 \mathrm{H}, y=6.0$ $11 \mathrm{~Hz}) .3 .50(\mathrm{dd}, 1 \mathrm{H}, J=3.0,10.5 \mathrm{~Hz}), 3.53$ (ddd. $1 \mathrm{H}, J=8.5,6,8.5 \mathrm{~Hz}) .3 .81(\mathrm{dd}$ $1 \mathrm{H} . J=11.8 .5 \mathrm{~Hz}), 3.87(\mathrm{dd}, 1 \mathrm{H} . J=10.5 .3 .5 \mathrm{~Hz}) .4 .31(\mathrm{dd} .1 \mathrm{H}, J=8.5 .1 \mathrm{~Hz})$ $4.74(\mathrm{~s}, 1 \mathrm{H}) .7 .07-7.74(\mathrm{~m}, 20 \mathrm{H}):{ }^{13} \mathrm{C}$ NMR $\left(125 \mathrm{MHz}, \mathrm{CDCl}_{3}\right): \delta=25.3 .25 .5$ 26.8. 54.1, 62.0.64.0,67.3, 71.7, 71.8, 127.5. 127.6.127.7, 128.3.128.3.128.7, 129.7. 129.7. 135.8

10: To a solution of $9(400 \mathrm{mg}, 0.66 \mathrm{mmol})$ in $5 \mathrm{~mL}$ toluenc at $-78 \mathrm{C}$ was added diisobutylaluminum hydride $(0.5 \mathrm{~mL}, 1.0 \mathrm{M}$ in hexane $)$ dropwise by syringe. After the addition was complete, the mixture was stirred at $-78 \mathrm{C}$ for $0.5 \mathrm{~h}$. The reaction was then quenched with $400 \mu \mathrm{L}$ methanol followed by addition of $4 \mathrm{~mL}$ of $10 \%$ aqueous solution of Rochelle's salt (potassium sodium tartrate) and $16 \mathrm{~mL}$ ether. The mixture was stired at room temperature for $1 \mathrm{~h}$, and the organic layer was washed with I $\mathrm{N} \mathrm{HCl}$ and saturated aqueous $\mathrm{N}_{4} \mathrm{HCO}_{3}$, and dried over $\mathrm{MgSO}_{4}$. The solvent was removed under vacuum and the residue purified by silica gel column chromatography (ethyl acetatc/hexane $=1: 10$ to $1: 3$ ) to give $366 \mathrm{mg}$ of 10 in $91 \%$ yield: $[x]_{j}^{23}=-7.2(c=1.15, \mathrm{MeOH}): R_{\mathrm{f}}=0.59$ (ethyl acetate hexane $=12$ ); ${ }^{1} \mathrm{HNMR}\left(500 \mathrm{MHz}, \mathrm{CDCl}_{3}\right): \delta=0.96$ (s. $\left.9 \mathrm{H}\right), 1.33(\mathrm{~s}, 3 \mathrm{H}), 1.40(\mathrm{~s}, 3 \mathrm{H}), 3.05-3.08$ (m, $1 \mathrm{H}), 3.30-3.41(\mathrm{~m} .3 \mathrm{H}), 3.74(\mathrm{dd}, 1 \mathrm{H} . J=10,5.5 \mathrm{~Hz}), 4.27$ (t. $1 \mathrm{H} . J=$ $5.5 \mathrm{~Hz}), 4.37-4.45(\mathrm{~m} .2 \mathrm{H}), 4.79$ (s. $1 \mathrm{H}), 7.47(\mathrm{~m}, 20 \mathrm{H}):{ }^{13} \mathrm{C}$ NMR $(125 \mathrm{MHz}$ $\left.\mathrm{CDCl}_{3}\right): \delta=21.8,26.5,26.7,59.8,62.5,63.3,66.9,71.4,73.8,73.9,127.2 .127 .3$ $127.8,128.3,128.4,128.5,129.6 .129 .7,135.3,135.4: \mathrm{HRMS}$ for $\mathrm{C}_{34} \mathrm{H}_{45} \mathrm{O}_{4} \mathrm{NSiCs}$ $\left[\mathrm{M}+\mathrm{Cs}^{+}\right]$: calcd 740.2172 . found 740.2170

1: To a solution of 10 (296 mg, $0.49 \mathrm{mmol})$ in $8 \mathrm{~mL}$ THF was added $1 \mathrm{~mL}$ of $1.0 \mathrm{~m}$ tetrabutylammonium fluoride in THF. The mixture was stirred at roon temperat ure for $30 \mathrm{~min}$. The solvent was then removed under reduced pressure. and the residue was dissolved in $15 \mathrm{~mL}$ methanol treated with $200 \mathrm{mg}$ of $p-\mathrm{TsOH} \cdot \mathrm{H}_{2} \mathrm{O}$. The mixture was stired at room lemperature overnight. After $2 \mathrm{~mL}$ of saturated aqucous $\mathrm{Na}$ $\mathrm{HCO}_{3}$ was added, the resulting mixture was stirred for another $10 \mathrm{~min}$. The methanol was removed under vacuum and the residue extracted with ethyl acetate and purified by silica gel column chromatography (ethyl acetate) to give $121 \mathrm{mg}$ of 10 a in $75 \%$ vield. $[\alpha]_{\mathrm{D}}^{2.5}+0\left(c=1.0 . \mathrm{CH}_{3} \mathrm{OH}\right): R_{\mathrm{f}}=0.18$ (ethy] acetate) ${ }^{1} \mathrm{H}$ NMR $\left(500 \mathrm{MH} / ., \mathrm{CD}_{3} \mathrm{OD}\right): \delta=3.1-3.2(\mathrm{~m}, 2 \mathrm{H}), 3.40(\mathrm{dd}, 2 \mathrm{H}, J=3.0 .11 .0 \mathrm{H} /) .3 .45$ $(\mathrm{dd}, 2 \mathrm{H}, J=6.0 .11 .0 \mathrm{~Hz}), 4.05-4.15(\mathrm{~m}, 2 \mathrm{H}) .5 .11(\mathrm{~s} .1 \mathrm{H}), 7.1-7.5(\mathrm{~m}, 10 \mathrm{H}):{ }^{13} \mathrm{C}$ NMR $\left(125 \mathrm{MHz}, \mathrm{CD}_{3} \mathrm{OD}\right): \delta=61.5 .65 .8 .72 .8 .73 .1 .128 .3,129.2,130.2 .143 .4$ HRMS for $\mathrm{C}_{1,} \mathrm{H}_{23} \mathrm{NO}_{4}\left[M+\mathrm{H}^{+}\right]$: calcd 330.1713 , found 330.1711 .

1: A solution of 10 a (90 mg. $0.27 \mathrm{mmol})$ in $10 \mathrm{~mL}$ methanol was hydrogenated with $30 \mathrm{mg}$ of $\mathrm{Pd}(\mathrm{OH})_{2}$ under hydrogen atmosphere at room temperature. After 6 h the catalyst was filtered off and washed with methanol. The combined methanol solutions were concentrated and the oily residue purified by silica gel column chromatography $\left(\mathrm{CHCl}_{3} / \mathrm{CH}_{3} \mathrm{OH} / \mathrm{H}_{2} \mathrm{O} / \mathrm{NH}_{4} \mathrm{OH}=5 / 4 ; 1,0.08\right)$ to give 1 : ' $\mathrm{HNMR}$ $\left(500 \mathrm{MHz}, \mathrm{CD}_{3} \mathrm{OD}\right): \delta=3.55-3.65(\mathrm{~m}, 2 \mathrm{H}), 3.88(\mathrm{dd}, 2 \mathrm{H}, J=8.0,12.0 \mathrm{~Hz}) .3 .92$ $(\mathrm{dd}, 2 \mathrm{H}, J=5.0,12.0 \mathrm{H} \%) \cdot 4.3 \cdots 4.4(\mathrm{~m} .2 \mathrm{H}) ;{ }^{13} \mathrm{C}$ NMR $(125 \mathrm{MHz} . \mathrm{CD}, \mathrm{OD})$ $\delta=59.45,63.08,71.69 ;$ HRMS for $\mathrm{C}_{6} \mathrm{H}_{1,3} \mathrm{NO}_{4}\left[M+\mathrm{H}^{+}\right]$: calcd. 164.0923, found 164.0911 : correct C.H.N analysis.

Chemoenzimatic symhesis of 1: Ozone was bubbled through a solution of 11 [10] $(302 \mathrm{mg} .1 .6 \mathrm{mmol})$ in methanol $(10 \mathrm{~mL})$ at $-78 . \mathrm{C}$ until the reaction solution became pale blue. After nitrogen was passed through the solution to remove excess ozone, the ozonide was treated with dimethylsulfide $(1 \mathrm{~mL})$ and water $(1 \mathrm{~mL})$ for 12 h at room temperature. Methanol was removed under vaceuum, and the residue was then purified by chromatography on Amberlite XAD-II $(3.0 \times 10 \mathrm{~cm} . \mathrm{H}, \mathrm{O})$ to yield 12. which was added to an aqueous solution of dihydroxyacetone phosphate (DHAP, $11 \mathrm{~mL} .0 .3 \mathrm{mmol}$ ). The $\mathrm{pH}$ of the solution was adjusted to 7.5 with $0.5 \mathrm{x}$ $\mathrm{NaOH}$. Fuculose-1-phosphate aldolase $(2.0 \mathrm{~mL} .70 \mathrm{U})$ was added to this solution and the mixture stirred slowly for $1 \mathrm{~d}$ at room temperature. After an enzymatic assay indicated that DHAP was completely consumed, the mixture was adjusted to pH 4.7 with $1 . \mathrm{N} \mathrm{HCl}$, acid phosphatase (from sweet potato type XA. $0.8 \mathrm{~mL} .200 \mathrm{U}$ ) was added. and the mixture was then stirred slowly at room temperature for $1 \mathrm{~d}$. The mixture was adjusted to $\mathrm{pH} 7.0$ with $0.5 \mathrm{~N} \mathrm{NaOH}$, and water was removed under reduced pressure. The residue was tredted with methanol. and the soluble portion was collected and purified by silica gel chromatography $\left(\mathrm{CHCl}_{3} / \mathrm{MeOH} / \mathrm{H}_{2} \mathrm{O}=8\right.$ $20.1)$ to vield compound $13(50.4 \mathrm{mg} .82 \%) .(x]_{D}^{23}=-13.5(c=0.60 . \mathrm{MeOH})$ 'H NMR $\left(400 \mathrm{MHz}, \mathrm{D}_{2} \mathrm{O}\right): \delta=3.50(1 \mathrm{H}, \mathrm{d}$ of AB type, $J=11.8 \mathrm{~Hz}), 3.60(1 \mathrm{H}$, $J=10.8 \mathrm{~Hz}) .3 .71(1 \mathrm{H}, \mathrm{d}$ of AB type, $J=11.80 \mathrm{~Hz}), 3.75(1 \mathrm{H}$, ddd, $J=10.80$. $9.92,5.60 \mathrm{~Hz}), 3.84(1 \mathrm{H}$. dd $J=10.80 .5 .60 \mathrm{~Hz}), 3.88(1 \mathrm{H}, \mathrm{d}, J=3.24 \mathrm{~Hz}) .3 .92$ $(1 \mathrm{H}, \mathrm{dd}, J=9.92,3.24 \mathrm{~Hz}):{ }^{13} \mathrm{C}$ NMR $\left(100 \mathrm{MHz}, \mathrm{D}_{2} \mathrm{O}\right): \delta=58.70,60.85,64.25$ 69.68, 70.37.98.65: HRMS for $\mathrm{C}_{6} \mathrm{H}_{11} \mathrm{~N}_{3} \mathrm{O}_{5} \mathrm{Na}\left[M^{+}+\mathrm{Na}\right]$ : caled 228.0596, found 228.0590 .

A solution of $13(28.4 \mathrm{mg}, 0.14 \mathrm{mmol})$ in ethanol $(10 \mathrm{~mL})$ was hydrogenated with $10 \% \mathrm{Pd}-\mathrm{C}(10 \mathrm{mg})$ under 50 psi of hydrogen for $12 \mathrm{~h}$. The catalyst was removed by filtration. and the solvent was evaporated under vacuum. The residue was purified by silica gel chromatography $\left(\mathrm{CHCl}_{3} / \mathrm{MeOH} / \mathrm{H}_{2} \mathrm{O} / \mathrm{NH}_{4} \mathrm{OH}=6 / 4 / 1 / 0.1\right)$ to yield compound $1(14 \mathrm{mg}, 61 \%)$. The NMR data $\left({ }^{1} \mathrm{H}\right.$ and $\left.{ }^{13} \mathrm{C}\right)$ are the same as those for 1 prepared chemically.

Received: February 14, 1994 [Z 6692 IE] German version: Angew: Chem. 1994. 106. 1343

[1] a) M. L. Sinnott, Chem. Rev. 1990, 90, 1171; b) B. Winchester, G. W. Fleet. Glucobiolog! 1992, 2, 199: c) G. C. Look. C. H. Fotsch, C.-H. Wong. Acc Chem. Res 1993, 26, 182.

[2] G. Papandreou, M. K. Tong, B. Ganem, J. Am. Chem. Soc. 1993, 115, 11682

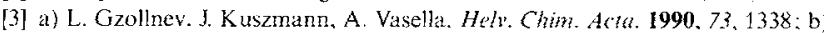
K. Wallimann, A. Vasella, ihid. 1991. 74. 1520.

[4] a) T. Kajimoto. K. K.-C. Liu, R. L. Pederson, Z. Zhong. Y. Ichikawa, J. A Porco, C.-H. Wong, J. Am. Chem. Soc. 1991, 113, 6187; b) G. Legler, S. Pohl Carbohydr. Res. 1986, 155, 119.

[5] a) K. K.-C. Liu, T. Kajimoto, L. Chen, Z. Zhong Y Ichikawa, C-H. Wong. J. Org. Chem. 1991, 56, 6280; b) Y.-F. Wang. D. P. Dumas, C.-H. Wong. Tetrahedron Letr. 1992, 34, 403; c) Y. Takaoka, T. Kajimoto, C.-H. Wong, J Org. Chem. 1993, 58.4809 ; d) G. W. J. Fleet, S. J. Nicholas, P. W. Smith. S. V. Evans, L. E. Fellows, R. L. Nash, Tetrahedron Lett. 1985, 26, 3127.

[6] A. B. Reitz, E. W. Bixter, Tetrahedron Lett. 1990. 31. 6777.

[7] D. B. Dess, J. C. Martin. J. Org. Chem. 1983, 48, 4156

[8] Recombinant fuculose-1-phosphate aldolase from $E$. coli was used. Procedure for overexpression of the enzyme will be published separately. We have deposited the microbial strain with the American Type Culture Collection (ATCC 86984), and it is available to the public. For other reports on the overexpression of this enzyme. see A. Ozaki. E. J. Toone, C. H. von der Osten. A. Sinskey. G M. Whitesides. J. Am. Chem. Soc. 1990,112,4970; W.-D. Fessner, G. Sinerius, A. Schneider, M. Dreyer, G. E. Schultz, J. Badia, J. Aguilar. Angew. Chem 1991. 103, 596: Angew. Chem. Lit. Ed. Engl 1991, 30. 555.

[9] R. L. Pederson. J. Esker, C.-H. Wong, Tetrahedron 1991, 47, 2643.

[10] R. R. Hung. J. A. Straub, G. M. Whitesides, J. Org. Chem. 1991, 56, 3849

[11] Crystal data for $2\left(\mathrm{C}_{1} \mathrm{H}_{13} \mathrm{NO}_{4} \mathrm{~S}\right)$ : orthorhombic. space group $P 2_{1} 2_{1} 2_{1}$ (No. 19 $\left.D_{2}^{4}\right), a=5.946(1), h=7.272(1), c=17.484(2) \AA, V=756.0(2) \AA^{3}, Z=4 . p$ $=1.434 \mathrm{~g} \mathrm{~cm}^{-3} \cdot M_{\mathrm{r}}=163.2 \mathrm{~g} \mathrm{~mol}^{-1}$, measurement at $293 \mathrm{~K}$ in the $20-0$ mode. Cu $u_{k \alpha}$ radiation, $i=1.54018 \AA, \mu \mathrm{Cu}_{\mathrm{k},}=0.112 \mathrm{~mm}^{-1} .741$ reflections measured $(4.0<2 \theta<120)$, of which 671 were independent and 633 with $F>2.0 \sigma(F)$ were used for refinement, 120 parameters, $\mathrm{GOF}=1.54, R=4.10, R_{\mathrm{w}}=5.13$ Further details on the crystal structure investigation will be provided elsewhere.

\section{Synthesis and Structure of the First Organometallic Galloxane Hydroxide $\mathrm{Mes}_{6} \mathrm{Ga}_{6} \mathrm{O}_{4}(\mathrm{OH})_{4}{ }^{* * *}$}

\section{Jens Storre, Thomas Belgardt, Dietmar Stalke, and Herbert W. Roesky*}

\section{Dedicated to Professor Hubert Schmidbaur on the occasion of his 60th birthday}

Recently structural investigations by Barron et al. revealed that the controlled hydrolysis of alkylaluminum compounds can afford both hydroxides and oxides. ${ }^{[1]}$ The formation of a mixed

[*] Prof. Dr. H. W. Roesky, Dipl-Chem. J. Storre, Dipl-Chem. T. Belgardt Priv.-Doz. Dr. D. Stalke Institut für Anorganische Chemie der Universitär Tammannstrasse 4. D-37077 Göttingen (FRG) Telefax: Int. code + (551)39-3373

[**] This work was supported by the Dentsche Forschungsgemeinschaft and the Fonds der Chemiscticn Industrie. Mes = mesityl. 
hydroxide oxide was not observed. The commercially used, partially hydrolyzed alkylaluminum compounds ${ }^{[2]}$ and the corresponding gallium compounds ${ }^{[3]}$ are important cocatalysts for metallocenes of group 4 of the periodic table. In considering polymerization reactions with metallocenes containing fluorine and methylaluminoxane as cocatalyst ${ }^{[4]}$ we were chiefly interested in the function and structure of the cocatalyst systems.

$$
\begin{aligned}
& \underset{\mathbf{M e s}}{2} \mathrm{GaCl}+\mathrm{KOH} \underset{-\mathrm{KCl}}{\longrightarrow} \mathrm{Mes}_{2} \mathrm{GaOH} \\
& 6 \mathrm{Mes}_{2} \mathrm{GaOH}+2 \mathrm{H}_{2} \mathrm{O} \underset{-6 \mathrm{MesH}^{-}}{\longrightarrow} \mathrm{Mes}_{6} \mathrm{Ga}_{6} \mathrm{O}_{4}(\mathrm{OH})_{4} \\
& \mathbf{3} \\
& \underset{2}{6 \mathrm{Mes}_{3} \mathrm{Ga}}+6 \mathrm{H}_{2} \mathrm{O} \underset{\text { toluene }}{\stackrel{-6 \mathrm{MesH}}{\longrightarrow}} 6 \mathrm{Mes}_{2} \mathrm{GaOH} \frac{+\mathrm{H}_{2} \mathrm{O}}{-6 \mathrm{MesH}} \mathbf{3}
\end{aligned}
$$

In order to obtain crystalline products, we carried out hydrolysis with $\mathrm{Mes}_{2} \mathrm{GaCl}$ (1) and $\mathrm{Mes}_{3} \mathrm{Ga}(2)$ (Mes = mesityl). Compound 1 reacts with hydrated $\mathrm{KOH}$ in THF leading to the formation of $\mathrm{KCl}$ and probably $\mathrm{Mes}_{2} \mathrm{GaOH}$ [Eq. (a)], which condenses to give $\mathrm{Mes}_{6} \mathrm{Ga}_{6} \mathrm{O}_{4}(\mathrm{OH})_{4}(3)$ [Eq. (b)]. The resulting $\mathrm{KCl}$ could be separated by filtration and MesH could be detected by ${ }^{1} \mathrm{H}$ NMR spectroscopy. In order to confirm this reaction pathway, we treated 2 with water in toluene [Eq. (c)], since the hydrolysis of organogallium compounds affords the corresponding gallium hydroxides. ${ }^{[5]}$ The reaction led to the formation of 3 and MesH. The condensation of the homologous aluminum compounds ${ }^{[6]}$ has so far not been explained unambiguously.

The IR spectrum of $\left[3(\text { thf })_{4}\right]$ shows the characteristic $\mathrm{OH}$ vibrations: a sharp band at 3671 for free and a broad band at $3521 \mathrm{~cm}^{-1}$ for bridging $\mathrm{OH}$ groups, which can be explained by partial release of the coordinating THF molecules. The EI mass spectrum shows the peak for the molecular ion at $m / z=1264$ and that of the hydroxide-free hexameric galloxane at $m$ / $z=1228\left(100 \%\right.$ rel. intensity, $\left.M^{+}-2 \mathrm{H}_{2} \mathrm{O}\right)$. In the ${ }^{1} \mathrm{H} N M R$ spectrum, two signals each are observed for the ring protons $(\delta=6.73-6.71)$ as well as for the ortho $(\delta=2.57-2.53)$ and the para $(\delta=2.18)$ methyl protons of the mesityl group. Thus, the mesityl groups are arranged differently. This is confirmed by the distorted octahedral structure in the solid state. The $\mathrm{OH}$ protons occur at $\delta=6.37$.

Single crystals suitable for X-ray structure analysis ${ }^{[7]}$ were obtained from THF. In addition to the four THF molecules coordinated to 3 , six uncoordinated THF molecules are present per formula unit. As a result of the latter the crystals disintegrate very rapidly as soon as the mother liquor is removed. The selection of the crystal and subsequent application was therefore carried out at $-50^{\circ} \mathrm{C} .{ }^{[8]}$ The hexanuclear mesitylgalloxane hydroxide 3 crystallizes in the space group $R 3 c$. The oxygen atoms $\mathrm{O} 4$ and $\mathrm{O} 3$ lie on the threefold axis (Fig. 1). To a first approximation the structure can be described as a distorted octahedron of six gallium atoms. Each face of this octahedron per hemisphere is capped alternately by an $\mu_{3}$-oxygen atom and a $\mu_{3}$-hydroxide group. All gallium atoms are formally in the oxidation state + III and are five-coordinate. This degree of coordination is not unusual for gallium compounds (e.g. in $\mathrm{Me}_{2} \mathrm{GaO}_{2} \mathrm{C}_{7} \mathrm{H}_{5}$; $\mathrm{O}_{2} \mathrm{C}_{7} \mathrm{H}_{5}=\alpha$-tropolyl) ${ }^{[12]}$ The hydroxidic oxygen atoms form significantly longer $\mathrm{Ga}-\mathrm{O}$ distances than the oxidic oxygen atoms (221 and $245 \mathrm{pm}$ for $\mathrm{O} 1$ and $\mathrm{O} 3$, respectively, in contrast to 187 and $189 \mathrm{pm}$ for $\mathrm{O} 2$ and $\mathrm{O} 4$, respectively). Furthermore, the environment of the hydroxidic oxygen atoms is more pyramidalized than that of the oxidic oxygen atoms ( $\mathrm{Ga}-\mathrm{O}-\mathrm{Ga}$ for $\mathrm{O} 1$ and $\mathrm{O} 388.1$ and $78.6^{\circ}$, respectively; in contrast for $\mathrm{O} 2$ and $\mathrm{O} 4110.7$ and $108.9^{\circ}$, respectively). This observation is consistent with the one made for $\mathrm{Mes}_{6} \mathrm{Ga}_{6} \mathrm{~F}_{4} \mathrm{O}_{4},{ }^{[13]}$ namely that the

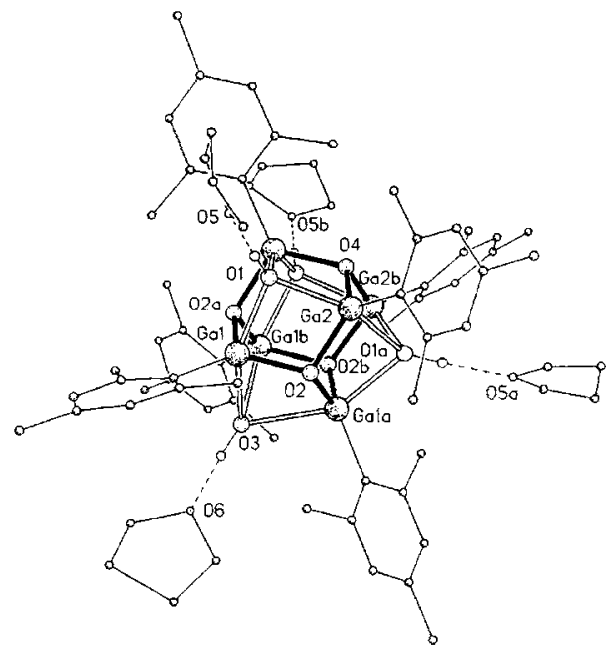

Fig. 1. Crystal structure of $\left[3(\text { thf })_{4}\right] \cdot 6$ THF. The six noncoordinated THF molecules are not shown. The bond lengths [pm] and angles ["] labeled with an * are a verage values, the numbers in square brackets are the range of values, the standard deviations are extreme values: $\mathrm{O} 1-\mathrm{Ga} 221(1)^{*}[213(1)-230(1)], \mathrm{O} 3-\mathrm{Ga} 245(1)$, O2-Ga 187(1)* [185.5(9)-189(1)], O4-Ga 189.3(5), Ga-C 196(1)* [195(1)197(1)]; Ga-O1-Ga 88.1(4)* [87.5(3)-88.6(3)], Ga-O3-Ga 78.6(4), Ga-O2-Ga $110.7(5)^{*}[107.6(4)-113.0(5)]$, Ga-O 4-Ga 108.9(5)

oxidic oxygen atoms form a comparable mean angle of $111.6^{\circ}$ $\left(105.9-117.7^{\circ}\right)$ with the two bound gallium atoms. The average $\mathrm{Ga}-\mathrm{C}$ distance of $196 \mathrm{pm}$ is in the range typical for arylgallium compounds. ${ }^{[14]}$ THF molecules in the spaces left by the six mesityl ligands coordinate by hydrogen bonds to the four $\mathrm{OH}$ functions of the $\mathrm{Ga}_{6} \mathrm{O}_{4}(\mathrm{OH})_{4}$ framework $(\mathrm{O} 1 \cdots \mathrm{O} 5273$ and $\mathrm{O} 3 \cdots \mathrm{O} 6252 \mathrm{pm})$. Coordination of this sort has already been described for $\left[\left(t \mathrm{Bu}{ }_{2} \mathrm{AlOH}\right)_{3} \cdot 2\right.$ thf $] .^{[1]}$

It is thus possible to prevent condensation through reaction of all hydroxide groups by the use of sterically demanding substituents. In addition Neumüller and Gahlmann observed the formation of the hexanuclear organogallium fluoride oxide $\mathrm{Mes}_{6} \mathrm{Ga}_{6} \mathrm{~F}_{4} \mathrm{O}_{4}$, isoelectronic to $3{ }^{[13]}$ in the partial hydrolysis of $\mathrm{Mes}_{2} \mathrm{GaF}$. It may well be possible that $\mathrm{OH}-$ metal interactions play a role not only in the polymerization, but also in the wateraccelerated zirconium-catalyzed carbalumination of alkynes. ${ }^{[15]}$

\section{Experimental Procedure}

3: a) A solution of $\mathrm{GaMes}_{3}(1.4 \mathrm{~g}, 3.3 \mathrm{mmol})$ in THF (20 mL) was added dropwise to a solution of $\mathrm{GaCl}_{3}(0.3 \mathrm{~g}, 1.7 \mathrm{mmol})$ in THF $(20 \mathrm{~mL})$ and stirred for $30 \mathrm{~h}$ at room temperature. Subsequently $\mathrm{KOH}(0.28 \mathrm{~g} .5 .00 \mathrm{mmol}$, not dried) was added to this solution and the resulting mixture was stirred for $5 \mathrm{~d}$ at room temperature under an inert atmosphere. After the $\mathrm{KCl}$ had been filtered off, the filtrate was concentrated under vacuum and the white solid obtained was washed with $n$-hexane $(20 \mathrm{~mL})$. Crystallization from THF afforded $0.9 \mathrm{~g}(66 \%)\left[3(\text { thf })_{4}\right]$. The decomposition temperature of the THF-free compound 3 lay above $350^{\circ} \mathrm{C}$. Correct elemental analysis for $\mathrm{C}, \mathrm{H}, \mathrm{Ga}$

${ }^{1} \mathrm{H}$ NMR $\left(250 \mathrm{MHz},\left[\mathrm{D}_{8}\right] \mathrm{THF}, \mathrm{TMS}_{\mathrm{ex}}\right) ; \delta=6.73-6.71(\mathrm{~m}, \mathrm{Ar}-\mathrm{H}), 6.37(\mathrm{~s}, \mathrm{OH})$, $2.57-2.53\left(\mathrm{~m}, 2,6-\mathrm{CH}_{3}\right), 2.19-2.17\left(\mathrm{~m}, 4-\mathrm{CH}_{3}\right)$; IR (nujol): $i\left[\mathrm{~cm}^{-1}\right]=3671 \mathrm{~s}$, $3521 \mathrm{~s}$, br., $3015 \mathrm{~s}, 1719 \mathrm{~m}, 1601 \mathrm{vs}, 1558 \mathrm{~s}, 1412 \mathrm{~m}, 1292 \mathrm{~m}, 1056 \mathrm{vs}, 1028 \mathrm{vs}, 848 \mathrm{~s}$, $703 \mathrm{~s}, 589 \mathrm{~m}, 543 \mathrm{~s}$.

b) Degassed water $(106 \mu \mathrm{L}, 5.9 \mathrm{mmol})$ was added by syringe to a solution of GaMes $_{3}(2.52 \mathrm{~g} .5 .9 \mathrm{mmol})$ in toluene $(100 \mathrm{~mL})$ at $-78^{\circ} \mathrm{C}$ and the mixture was stirred and slowly allowed to warm to room temperature. Subsequently it was stirred for $3 \mathrm{~d}$, the volatiles were removed under vacuum, the white residue washed with $n$-hexane $(20 \mathrm{~mL})$ and filtered. The residue was dried under vacuum $\left(10^{-4}\right.$ mbar $)$ for about $15 \mathrm{~h}$. Yield of $3(0.72 \mathrm{~g}, 58 \%)$. Correct elemental analysis of $\mathrm{C}$ and $\mathrm{H}$ for $\mathrm{Mes}_{6} \mathrm{Ga}_{6} \mathrm{O}_{4}(\mathrm{OH})_{4}$. IR and NMR spectra in [D $]$ THF were consistent with those for the product prepared according to method a).

Received: January 21, 1994 [Z6637 IE] German version: Angew. Chem. 1994, 106, 1365 
[1] M. R. Mason. J. M. Smith, S. G. Bott. A. R. Barron, J. Am. Chem. Soc. 1993, 115, 4971.

[2] H. Sinn, W. Kaminsky, Adv. Organomet. Chem. 1980, $18,99$.

[3] K. Ziegler, GB-B 775384. 1957: Chen. Abstr. 1958, 52, $12893 \mathrm{e}$

[4] A. Herzog. H. W. Roesky, Z. Zak, M. Noltemeyer, Angew. Chem. 1994, 106 1035: Angew. Chem. Int. Ed. Engl. 1994, 33,967.

[5] D. A. Atwood, A. H. Cowley, P. R. Harris. R. A. Jones, S. U. Koschmieder, C. M. Nunn. Organometallics 1993, 12. 24.

[6] S. Pasynkiewiez, Pollhedron 1990. 9, 429.

[7] Crystal data of [3(thf $\left.)_{4}\right] \cdot 6$ THF: $M=1986.46$, rhombohedral, space group $R 3 c \cdot a=b=2353.6(3), c=3133.0(6) \mathrm{pm}, V=15.030(4) \mathrm{nm}^{3}, Z=6, \rho_{\text {calcd }}=$ $1.317 \mathrm{Mgm}^{-3} . \quad F(000)=6264, \quad \lambda=71.073 \mathrm{pm}, \quad T=-120 \mathrm{C}, \quad \mu\left(\mathrm{Mo}_{\mathrm{K} a}\right)=$ $1.651 \mathrm{~mm}^{-1}$. crystal dimensions: $0.7 \times 0.5 \times 0.5 \mathrm{~mm}, 6 \leq 20 \leq 40$; of the 6127 collected reflections, 2440 are independent, and these were used for the refinement of 164 parameters with the help of 198 restraints; maximal residua electron density: $899 \mathrm{enm}^{-3} \cdot R 1(F>4 \sigma(F))=0.069$ and $n R 2=0.199$ (all data) with $R 1=\Sigma|| F_{0}|-| F_{\mathrm{c}}|| i \Sigma\left|F_{0}\right|$ and $\left.n R 2=\left(\sum_{n} F_{0}^{2}-F_{c}^{2}\right)^{2} ; \sum m\left(F_{0}^{2}\right)^{2}\right)^{0.5}$ The data were collected on a Stoe-Huber diffractometer. Intensities of a rapidly cooled crystal in an oil drop [8] were collected by $20 \%$ method. Semiempirical absorption corrections were carried out on all data. The structure was solved by direct methods (SHELXS-90) [9] and refined by least squares on $F^{2}$ [10]. The disorders of the THF solvent molecules were refined with distance restraints. The refinement of the inversion twinning paramter [11] $(x=0.00(4)$ for $x=0$ for the correct absolute structure and $x=+1$ for the inverted structure) confirmed the absolute structure of 3 . The solution of the structure and the refinement in the space group $R \overline{3} c$ were unsuccessful. The structure could be solved in the space group $C a$, but a refinement was also here unsuccessful. Further details of the crystal structure investigation may be obtained from the Director of the Cambridge Crystallographic Data Centre. 12 Union Road, GB-Cambridge CB2 1EZ, on quoting the full journal citation.

[8] T. Kottke, D. Stalke, J. Appl. Crrstallogr. 1993, 26,615.

[9] G. M. Sheldrick, Acta Crystallogr. Sect. A 1990, 46, 467.

[10] G. M. Sheldrick, SHELXL-93, program for crystal structure refinement, Göttingen, 1993

[11] H. D. Flack. Acta Critallogr. Sect. A 1983. 39, 876.

[12] I. Waller. T. Halder. W. Scharz, J. Weidlein, J. Organonet. Chem. 1982, 232, 99

[13] B. Neumüller. F. Gahlmann, Angew. Chem. 1993. 105. 1770; Angen. Chem. Int Ed. Eng/. 1993, 32, 1701.

[14] O. T. Beachley, Jr.. M. R. Churchill. J. C. Pazik, J. W. Ziller. Organometallic I986, 5, 1814

[15] P. Wipf. S. Lim. Anger. Chem. 1993. 105, 1095; Angew. Chem. Int. Ed. Engl. 1993, 32, 1068 .

\section{Benziporphyrin, a Benzene-Containing, Nonaromatic Porphyrin Analogue}

\section{Kurt Berlin and Eberhard Breitmaier*}

An interesting approach for modifying the basic porphyrin framework for the most varied applications ${ }^{[1]}$ is replacing the pyrrole ring by another five-membered ring heteroarene such as furan and thiophene, ${ }^{[2]}$ or by pyridine ${ }^{[3,4]}$ or benzene. When 1,3disubstituted six-membered rings are incorporated, the macrocycle can achieve $18 \pi$ aromaticity only at the expense of the $6 \pi$ aromatic system. The obvious question is which of the two rings wins this competition. Recently we reported on the synthesis of a modified porphyrinogen in which a pyrrole is replaced by a pyridine unit. ${ }^{[4]}$ However, we could not obtain the $18 \pi$ aromatic tautomer with maximum unsaturation which corresponds to a porphyrin. The oxidation of the pyriporphyrinogen ${ }^{[4]}$ leads to the ketone instead.

We report here on the first benzene-containing macrocycle that is a porphyrin analogue, which in contrast to the pyriporphyrins, ${ }^{[4]}$ was obtained simply by oxidation of the appropriate porphyrinogen 3 . Tripyrranedicarboxylic acid $2 \mathbf{b}^{[5]}$ was decar-

[*] Prof. Dr. E. Breitmaier, Dipl.-Chem. K. Berlin

Institut für Organische Chemie und Biochemie der Universität

Gerhard-Domagk-Strasse 1, D-53121 Bonn (FRG)

Telefax: Int code $+(228) 73-568$<smiles>[R2]C(=O)c1[nH]c(Cc2[nH]c(Cc3[nH]c(C([R])[R])c(C)c3CC)c(CC)c2CC)c(CC)c1C</smiles>

1

$2 \mathrm{a}: \mathrm{R}=\mathrm{Bn}$ $2 \mathrm{~b}: \mathrm{R}=\mathrm{H}$
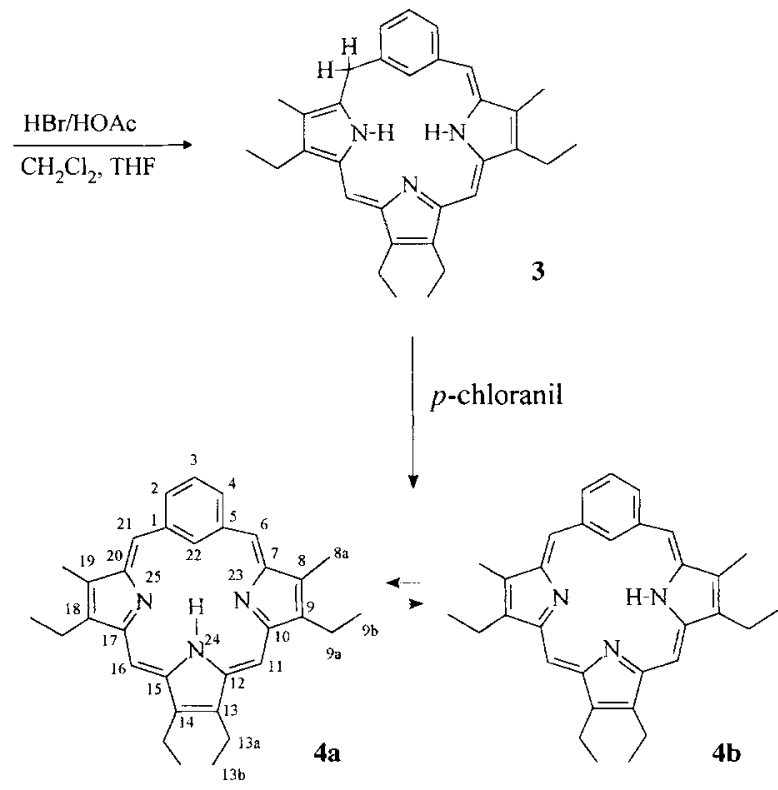

boxylated in situ and condensed with isophthalaldehyde (1) in dichloromethane/THF with $33 \% \mathrm{HBr}$ in glacial acetic acid as the catalyst. The resulting macrocycle was then oxidized in situ with p-chloranil to give $\mathbf{4}$. In analogy to pyriphorphin we propose the name benziporphin for the unsubstituted framework and the numbering shown for $\mathbf{4 a}$.

The spectroscopic data for the compound give no indication of $18 \pi$ aromaticity and cyclic conjugation in the tautomer. The UV spectrum, for example. does not display the Soret band $(420 \mathrm{~nm}, \lg \varepsilon>4)$ characteristic of porphyrins, and in the ${ }^{1} \mathrm{H}$ NMR spectrum the pyrrole-NH protons $(\delta=8.90)$ and the inner benzenoid protons $(\delta=7.88)$ do not show the shielding typical for the inner protons of an [18]annulene. Thus the tautomers $\mathbf{4 a} / \mathbf{b}\left(4: 1\right.$ in $\left.\mathrm{CDCl}_{3}\right)$ have an intact benzenoid arene unit. It is apparent that the aromatic $18 \pi$ tautomer does not exist even when only one $6 \pi$ arene would have to be sacrificed. Thus 4, a prototype of macrocycles in which benzenoid rings successively replace the pyrrole rings of porphyrin, indicates that porphyrin analogues with more than one $6 \pi$ arene $^{[6]}$ cannot be [18]annulenes.

The successful preparation of $\mathbf{4}$ also implies that the surprising behavior of the "pyriporphyrinogens" [4] towards oxidants results from the side reaction of the reactive $\alpha$-alkyl group of the pyridine rings and is not a consequence of the unattainable $18 \pi$ aromaticity.

\section{Experimental Procedure}

Diester 2 a $(635 \mathrm{mg}, 1 \mathrm{mmol})$ was dissolved in $80 \mathrm{~mL}$ of anhydrous THF and treated with $200 \mathrm{mg}$ of $\mathrm{Pd} / \mathrm{C}(10 \% \mathrm{Pd})$ and $0.1 \mathrm{~mL}$ of triethylamine. After $3 \mathrm{~h}$ of hydrogenation at ambient pressure the catalyst was removed by vacuum filtration and the filtrate (2 b) added dropwise to a solution of isophthalaldehyde (1) (134 mg, $1 \mathrm{mmol}$ ) in $800 \mathrm{~mL}$ of dichloromethane. Argon was then bubbled through the reaction mixture for $15 \mathrm{~min}$, and then $1.8 \mathrm{~mL}$ of a solution of $\mathrm{HBr}$ in glacial acetic acid $(33 \%)$ was added. The reaction mixture was stirred for $4 \mathrm{~h}$ with exclusion of light. $750 \mathrm{mg}$ of $p$-chloranil was added, and 15 min later the reaction mixture was neutralized with $2.5 \mathrm{~mL}$ of triethylamine and left to stand ca. $15 \mathrm{~h}$. The solvent was removed under 